Jolanta Fiszbak

Uniwersytet Łódzki

DOI 10.19195/1642-5782.14(24).3

\title{
O potrzebie sięgnięcia do tradycji polonistycznej w zakresie kształcenia językowego
}

Przeglądając biblioteczkę emerytowanej przed piętnastu laty nauczycielki, natrafiłam na pozycję zasłużonej dla dydaktyki języka polskiego Karoliny Pojawskiej, poświęconą ćwiczeniom w mówieniu i pisaniu ${ }^{1}$. Szybko skonstatowałam, że książeczka warta jest głębszej lektury, a szczególne zainteresowanie (o czym dalej) wzbudził wstęp do niej:

Przeświadczenie o słuszności myśli poety, że „Człowiek ze swoją mową zrośnięty jest ciaśniej niż drzewo z ziemią" [M. Jastrun, Poemat o mowie polskiej], powinno towarzyszyć nauczycielowi języka polskiego w jego codziennej pracy dydaktyczno-wychowawczej.

Szkoła nasza w okresie realizacji uchwały o zmianie form i treści programów nauczania stanęła wobec nowych szczytnych obowiązków, wynikających z istoty przemian naszego życia społecznego, kulturalnego i politycznego. Rzeczywistość zrodzona przez te przemiany, bardzo bogata i ciekawa, niosąca niemal codziennie „nowe”, jest główną inspiratorką przebudowy systemu szkolnego. Dziś, gdy wiedza i wychowanie mają urabiać charakter człowieka $[\ldots]^{2}$, rozwijanie w dzieciach i młodzieży miłości i szacunku dla własnego języka jest zarazem kształtowaniem szlachetnej dumy narodowej i tworzeniem więzi społecznej — łączącej obywateli w ich twórczej pracy. [...] $]^{3}$

${ }^{1}$ K. Pojawska, Ćwiczenia w mówieniu i pisaniu w klasach V-VIII, Warszawa 1967.

2 Usunięto fragment: „budowniczego socjalizmu”.

3 Ibidem, „wiąże młodzież z Polska Ludową, kształtuje postawę zaangażowania społecznego oraz gotowość kontynuowania dzieła budownictwa socjalistycznego [Program nauczania ośmioklasowej szkoły podstawowej. Język polski. Warszawa 1963. PZWS, s. 159]”. Nie ma potrzeby zastanawiać się, czy występujące we Wstępie wzmianki o Polsce Ludowej i budownictwie socjalistycznym są efektem osobistych przekonań autorki, czy też wynikiem konieczności ich pojawienia się, by ta ważna i cenna książka, wielokrotnie wznawiana, mogła ujrzeć światło dzienne. Życiorys K. Pojawskiej: udział w Powstaniu Warszawskim i w tajnym nauczaniu oraz charakterystyczna dla jej pokolenia potrzeba służby ojczyźnie, zob. Pamięci Karoliny Pojawskiej, http://www.um.kielce. pl/pomitab/obiekty/pojawska [dostęp: 28.12.2015]; J. Stankiewicz, Nauczyciele tajnego nauczania, 
To ważne wychowawcze zadanie języka polskiego nauczyciel będzie realizował rozmaitymi sposobami, ale przede wszystkim przez rozwijanie i utrwalanie sprawności posługiwania się językiem ojczystym w mowie i piśmie. Ćwiczenia w mówieniu i pisaniu stanowią ten dział programu, którego właściwe i poprawne opracowanie pozwoli osiągnąć określone cele wynikające z ogólnych zadań szkoły podstawowej ${ }^{4}$.

Gdyby nie treści, które kryją się za opuszczonymi fragmentami (zob. przyp. 2 i 3), można by sądzić, że tekst powstał w ciągu ostatnich kilkunastu lat, mimo że od 1999 r. nastąpiły znaczące zmiany w strukturze kształcenia językowego. Jolanta Nocoń zwróciła uwagę, że do reformy ten dział języka polskiego jako przedmiotu obejmował ćwiczenia w mówieniu i pisaniu oraz naukę o języku, natomiast po reformie główny nacisk położono na rozwijanie i doskonalenie kompetencji komunikacyjnej ${ }^{5}$.

Zamykając rozważania na temat pracy K. Pojawskiej, wskażmy jeszcze na dość charakterystyczną różnicę między Wstępem do Ćwiczeń w mówieniu i pisaniu jej autorstwa a analogicznymi tekstami, powstającymi współcześnie. Charakteryzuje go pewna wzniosłość i odświętność, które zauważamy w odwołaniu się autorki do myśli poety, podkreśleniu, że szkoła jest n a s z a, w sformułowaniach: „szczytne obowiązki”, rozwijanie w uczniach „uczucia miłości i szacunku dla własnego języka, kształtowanie szlachetnej dumy narodowej”, w ujęciu ,język ojczysty". To nie są czcze frazesy. Wypowiedziom współczesnych dydaktyków brakuje tego uroczystego charakteru, świadczącego o posłannictwie, zaszczycie i potrzebie służenia ojczyźnie. Nie będziemy rozstrzygać, czy wynika to tylko $\mathrm{z}$ unaukowienia myśli dydaktycznej, czy też tendencji myśli ponowoczesnej, z charakterystycznym dla niej relatywizmem kulturowym. Być może i tu kryje się przyczyna gorszego wykształcenia Polaków po reformie strukturalnej — bardziej niż przewodnikiem i mistrzem nauczyciel jawi się dziś jako urzędnik wykonujący swoją pracę w zakreślonych obowiązkami granicach.

Celem niniejszego artykułu jest zwrócenie uwagi na te niedomagania kształcenia językowego, które powodują/mogą powodować ogólne obniżenie się sprawności językowej młodego pokolenia Polaków. W pierwszej części rozważań uwaga zostanie zwrócona na przeobrażenia, jakim zaczął podlegać ten dział języka polskiego jako przedmiot oraz na niedostateczne przygotowanie znacznej liczby nauczycieli polonistów do wprowadzania zmian proponowanych przez dydaktyków. Część druga natomiast zostanie poświęcona przypomnieniu korzyści, które dawało tradycyjne podejście do kształcenia językowego. Zostało ono w znacznym stopniu zarzucone między innymi pod wpływem nowych koncepcji. Warto również zauważyć, że chociaż większość podręczników i programów do

uczestnicy ruchu oporu 1939-1945 (województwo kieleckie), http://www.stankiewicze.com/index. php?kat=38\&sub=854 [dostęp: 28.12 .2015 ].

${ }^{4}$ K. Pojawska, op. cit., s. 5.

5 J. Nocoń, Uczenie o języku polskim po 1998 roku — prognozy i koncepcje dydaktyczne, [w:] Uczeń w świecie języka i tekstów, red. J. Nocoń, E. Łucka-Zając, Opole 2010, s. 27-30. 
tego właśnie modelu się odwołuje, to jednak ograniczenie liczby godzin na realizację treści programowych spowodowało wypaczenia jego idei.

Zacznijmy od tego, że niedługo po transformacji ustrojowej zaczęła się dyskusja nad szkolnym kształceniem językowym. Problem dotyczył krytyki jego ówczesnego kształtu - nadmiaru gramatyki w szkole, koncentrowaniu się na teorii językowej, a także celów szkolnej nauki o języku: podkreślano, że nabycie wiedzy teoretycznej nie wpływa na sprawność językową. W późniejszych opracowaniach posunięto się nawet do stwierdzenia, że był to okres utożsamiania kształcenia językowego z nauką o języku ${ }^{6}$, co jest nadużyciem, ponieważ obejmowało ono gramatykę (jak potocznie nazywano naukę o języku) oraz ćwiczenia w mówieniu i pisaniu. Te były elementem integrującym kształcenie literackie z językowym i spajającym całość kształcenia polonistycznego, o czym informacje można było znaleźć w każdym kompendium wiedzy podejmującym to zagadnienie.

Niechęć do szkolnej nauki o języku mogła wynikać z dwóch powodów. Przede wszystkim — z nieudolnego jej nauczania, ograniczającego się do wyodrębniania i klasyfikowania zjawisk gramatycznych oraz analizy martwych preparatów językowych. Była to nauka nudna, martwa już u podstaw, powodująca, że uczeń najczęściej nie łączył poznawanej wiedzy ze zjawiskiem, które towarzyszyło mu na co dzień. Drugim powodem, równie ważnym, choć rzadziej podnoszonym, była niespójność między gramatyką szkolną a uniwersytecką. Ta pierwsza tkwiła korzeniami w XIX w. i nie nadążała za zmianami dokonującymi się w nauce, co czyniło ją w pewnym stopniu anachroniczną. Teorie językoznawcze, choć nienauczane, pojawiły się jednak w praktyce szkolnej, o czym w interesujący sposób pisała Ewa Horwath ${ }^{7}$, zbliżając dydaktykę szkolną do uniwersyteckiej.

„Wojna o kształcenie językowe”, jak Piotr Zbróg nazwał dyskusję nad tym działem języka polskiego jako przedmiotu, rozpoczęła się około połowy lat 90., warto jednak pamiętać, że jej korzenie tkwią w dwudziestoleciu międzywojennym $^{8}$. Wtedy właśnie podjęto starania o realizację autonomicznych celów nauczania gramatyki i teorię językową wprowadzono do szkoły, upatrując $\mathrm{w}$ jej realizacji ważnych elementów kształcących i wychowawczych. Skoncentrujemy się jednak tylko na okresie najbliższym. W 1994 r. Maria Nagajowa podkreślała potrzebę istnienia w szkole teorii językowej, która służyłaby kształtowaniu umiejętności językowych i zaproponowała, by gramatykę teoretyczno-normatywną zastąpić gramatyką funkcjonalną. Była przeciwna budowaniu świadomości teoretycznej

6 „Dopiero podręcznik To lubię — pisał Piotr Zbróg — przełamał niejako stereotyp utożsamiania kształcenia językowego z nauką o języku". Autor przypomniał też perypetie z wycofaniem wspomnianego podręcznika z użytku szkolnego. Zob. P. Zbróg, Wojna o kształcenie językowe, Kielce 2005 , s. 31.

7 E. Horwath, Teorie językoznawcze w szkolnej dydaktyce, [w:] Szkolna polonistyka zanurzona w języku, red. A. Janus-Sitarz, E. Nowak, Kraków 2014, s. 63-86.

8 Przypomnijmy choćby prace Jana Baudoina de Courtenay, Zenona Klemensiewicza, Stanisława Szobera lub Jana Rozwadowskiego. Zob. J. Fiszbak, O celach szkolnej nauki o języku, [w:] Z dydaktyki języka ojczystego w szkole, red. S. Gala, Łódź 1996, s. 7-26. 
jako celu samego w sobie ${ }^{9}$. W tymże samym roku Kordian Bakuła na łamach „Polonistyki” sprzeciwił się nadmiarowi gramatyki w szkole; proponował położyć nacisk na pragmatykę językową i kształcenie kompetencji komunikacyjnych. Jego zdaniem wiedza o języku oraz ćwiczenia w mówieniu i pisaniu powinny być powiązane $\mathrm{z}$ lingwistyką tekstu ${ }^{10}$. Propozycja ograniczenia zakresu szkolnej gramatyki wywołała burzliwą dyskusję na łamach „Polonistyki”. Wypowiadali się wówczas między innymi Tadeusz Zgółka, Franciszek Nieckula, Jadwiga Puzynina, Stanisław Gajda ${ }^{11}$. Stwierdzano, że wiedza językowa w szkole jest konieczna, ponieważ pomaga doskonalić umiejętności posługiwania się językiem, służy pracy nad dziełem literackim, ułatwia uczenie się języków obcych, wreszcie uczniowie powinni być w nią wyposażeni, albowiem język jest narzędziem poznania, a przede wszystkim jest wartością samą w sobie. Możemy dodać jeszcze, że szkolna wiedza o języku ułatwia też nauczanie teorii językowej w szkole i daje podstawy do poznawania językoznawstwa uniwersyteckiego, budzi świadomość językową i może przyczyniać się do kształtowania szacunku dla języka.

Kolejne próby zreformowania szkolnej nauki o języku podporządkowane były pragmatyce językowej i sprawnościom komunikacyjnym w aspekcie nadawczo-odbiorczym, w tym w rozwijaniu kompetencji tekstotwórczej. Wymienić tu należy przynajmniej prace Piotra Zbróga, Agnieszki Rypel lub najnowszą propozycję Jadwigi Kowalikowej ${ }^{12}$. Zatrzymajmy się na krótko przy koncepcjach P. Zbróga i J. Kowalikowej. Pierwszy model kształcenia językowego zasadza na przekonaniu, ,że o języku i komunikacji należy w miarę możliwości [wyr. - J.F.] mówić całościowo, łącząc ze sobą wybrane aspekty każdej sytuacji komunikacyjnej”'13. Punktem wyjścia pracy na lekcji powinna być sytuacja komunikacyjna, uwzględniająca komponenty: językowy (a w jego ramach aspekt leksykalno-stylistyczny i gramatyczno-ortograficzny) i niejęzykowy (z aspektem werbalnym i kulturowym) sytuacji komunikacyjnej. Komponent gramatyczny (wiedza o języku „mniej lub ściślej powiązana z treściami komunikacyjnymi”) z sytuacją komunikacyjną łączyłby się nie tylko okazjonalnie; należy go ujmować jako celowo zaplanowany i rozwijający wiedzę o języku: treści gramatyczne

9 M. Nagajowa, Nauka o języku dla nauki języka. Poradnik metodyczny dla nauczycieli języka polskiego, Kielce 1994, s. 11.

10 K. Bakuła, Szkolna naukę o języku trzeba zmienić, „Polonistyka” 1994, nr 5, s. 274-281.

11 S. Gajda, Trudne upotrzebnienie, „Polonistyka” 1996, nr 6, s. 240-241; F. Nieckula, Usunać język polski z ,języka polskiego”?, „Polonistyka 1995, nr 4, s. 214-220; idem, Primum non nocere, „Polonistyka” 1996, nr 6, s. 241-242; J. Puzynina, Gramatyka na 10 głosów, „Polonistyka” 1996, nr 6, s. 238-239; T. Zgółka, Barbarzyńca w (szkolnym) ogrodzie, „Polonistyka” 1995, nr 4, s. $213-214$.

12 Zob. np. P. Zbróg, op. cit.; A. Rypel, Nauczanie komunikacyjne w ksztatceniu uczniowskich wypowiedzi pisemnych. Problemy. Badania eksperymentalne. Implikacje dydaktyczne, Bydgoszcz 2007; J. Kowalikowa, Od stowa do zdania, od zdania do tekstu — od tekstu do zdania, od zdania do słowa, [w:] Szkolna polonistyka zanurzona..., s. 17-43.

13 Por. P. Zbróg, op. cit., s. 82. 
powinny być wprowadzane do jednostek lekcyjnych w taki sposób, by tworzyły spójną całość logiczną w ciągu kształcenia. Autor zauważa jednak, że integracja treści językowych z komunikacyjnymi ze względu na specyfikę nauki o języku nie zawsze jest możliwa ${ }^{14}$.

Z kolei propozycja J. Kowalikowej odpowiada „tekstocentrycznemu” charakterowi obowiązującej obecnie podstawy programowej, która - jak podkreśla autorka - po latach zaniedbań i krytyki docenia naukę o języku, przy czym większy nacisk kładzie na użycia języka i ich efekty niż na realizację celów autonomicznych ${ }^{15}$. Pracę na lekcji wyznacza zawarty w tytule kierunek działań: $O d$ stowa do zdania, od zdania do tekstu - od tekstu do zdania, od zdania do stowa, zakładający konfrontację całości tekstu z jego składnikami. J. Kowalikowa proponuje na zasadzie obligatoryjności przyjąć dwa punkty wyjścia: od szczegółu do ogółu i na odwrót, co umożliwi odpowiedź na pytania: o czym jest przeczytany tekst?, jak ów tekst zostat „,zrobiony” z języka?, co wynika z wcześniejszych konstatacji dla odbiorcy? Wskazuje także na dwa warianty procesu dydaktycznego. Pierwszy zakłada, że przyszły autor tekstu traktuje cudzy komunikat nie tylko jako źródło informacji, lecz także jako wzorzec do wykorzystania. Drugi - że autor powraca do napisanych wcześniej przez siebie wypowiedzi i korzystając z nabytego w okresie późniejszym doświadczenia, dokonuje ich korekty, wprowadzając poprawki i ucząc się na własnych błędach ${ }^{16}$. W rozwijaniu świadomości językowej i kompetencji tekstotwórczej wpisanej w podstawę programową zadaniem autorów programów szczegółowych i podręczników jest, według J. Kowalikowej, dobór odpowiedniego materiału nauczania, dydaktyków uniwersyteckich — zastanowienie się nad stroną metodyczną, a nauczycieli — decyzja o podjęciu konkretnych rozwiązań praktycznych ${ }^{17}$. Już z tej konstatacji wynika, że mamy do czynienia z przemyślaną propozycją rozwiązań, lecz jeszcze nie z konkretną koncepcją kształcenia językowego.

Mimo wyraźnego ograniczenia teorii językowej w szkole i położenia nacisku na umiejętności językowe, jednak pod tym względem one się nie poprawiły, a wielu absolwentów szkoły ponadgimnazjalnej przejawia problemy z redakcją prostych tekstów, na przykład nie może sprostać wymogom tak podstawowej formy wypowiedzi, jaką jest opis ${ }^{18}$. Propozycje P. Zbróga i J. Kowalikowej, choć ukierunkowane na rozwój kompetencji językowych ucznia, mają charakter laboratoryjny i nie wiadomo, jak sprawdzą się w praktyce. Wcielający je w życie nauczyciel powinien też starannie przemyśleć wprowadzenie proponowanych ćwiczeń. Niektóre zadania P. Zbróga, na przykład, przypominają stosowane kil-

14 Ibidem, s. 83-85.

15 J. Kowalikowa, op. cit., s. 20-21.

16 Ibidem, s. 20-21.

17 Ibidem, s. 25.

18 Problemy takie sygnalizowali nauczyciele akademiccy kierunków ścisłych. Ich studenci nie potrafili zredagować opisu doświadczenia laboratoryjnego. 
kadziesiąt lat temu formy wychowawcze wykorzystujące gry symulacyjne (zob. Nawiazujemy pierwszy kontakt $^{19}$ ), które po początkowym zainteresowaniu powodowały rozbawienie uczniów starających się ,uatrakcyjnić" swoją prezentację ${ }^{20}$. Dzisiejszy uczeń jest w pewien sposób dojrzalszy (choć i jemu przydałaby się lekcja grzeczności) i podobne gry mogą nie budzić jego zaciekawienia. Warto też zwrócić uwagę na pewne pułapki czyhające na kogoś nieobznajomionego z teorią. Lekcja poświęcona językowi niewerbalnemu ukierunkowana jest na zachowania sygnalizujące to, co rozmówca stara się ukryć, na przykład kłamstwo, niepewność, oszustwo ${ }^{21}$. Rzecz w tym, że ukazane zachowania mogą, ale nie muszą ich zdradzać: na przykład zakrywanie ust nie zawsze oznacza mówienie nieprawdy. Należy też zauważyć, że niektóre polecenia pozornie tylko łatwe są w wykonaniu:

Podajcie przykłady pytań rytualnych (zwyczajowych) zadawanych podczas pierwszego kontaktu [...]; Napisz po dwa przykłady zdań, które mogą służyć za początek rozmowy. a. prosisz o informacje; b. mówisz coś miłego; c. nawiązujesz do aktualnych zdarzeń ze szkoły, kultury, sportu) [...]; Ustal z kolegą [...] pięć pytań, które można zadać podczas pierwszego kontaktu z właśnie poznaną osobą, aby zdobyć informacje o niej $[\ldots]^{22}$.

Podobne w charakterze ćwiczenia znajdziemy także w propozycji J. Kowalikowej, na przykład: rozwijanie zdania pojedynczego, zawierającego dwa, trzy składniki, o kolejne ${ }^{23}$. Jak zauważono, nie są to zadania proste, tym bardziej jeśli uczeń kształci dopiero swoje kompetencje językowe. Język odwzorowuje rzeczywistość pozajęzykową i potrzebne obrazy (,,pomysły”) mogą się nie pojawić na zawołanie w umyśle dziecka, a nawet starszego ucznia. Problemów z wykonaniem tych ćwiczeń nie będzie miał uczeń dysponujący bogatym słownictwem i w miarę szeroką wiedzą o świecie. Sytuacje takie charakteryzuje też pewna sztuczność, która dodatkowo może nastręczać trudności.

19 Por. P. Zbróg, op. cit., s. 115.

20 Zadaniem uczniów było, na przykład, symulowanie wejścia do pokoju nauczycielskiego w celu zapytania o coś lub odebranie jakiegoś przedmiotu (np. dziennika). Należało cicho, ale wyraźnie zapukać do drzwi, poczekać na zaproszenie, wejść, przywitać się, przedstawić, podać przyczynę przyjścia, a następnie podziękować za pomoc, pożegnać się i niezwłocznie wyjść. Trzeba było przy tym zachowywać się spokojnie i nie rozglądać się bez potrzeby. Każdy z uczniów chciał się zaprezentować - było to coś nowego - ale po kolejnej symulacji dość szybko zaczynała się niekontrolowana zabawa.

21 P. Zbróg, op. cit., s. 139.

22 Ibidem, s. 16.

23 J. Kowalikowa, op. cit., s. 23. Podobne ćwiczenia starałam się wcielić w życie trzy dekady temu podczas pracy z trzynastoletnią uczennicą, której język był bardzo ubogi, pisała na przykład wypracowania, używając tylko zdań pojedynczych. Nie powiodło się ani ich rozwijanie o kolejne składniki, ani też próba wprowadzenia do jej świadomości istnienia zdań podrzędnie złożonych przez stosowanie parafrazy składniowej. Nie mogłam wówczas zrozumieć, dlaczego tak się dzieje, skoro nie była to uczennica, którą charakteryzowałyby — jak to dziś byśmy nazwali — deficyty rozwojowe (zarówno ona, jak i jej rodzice nastawieni byli na karierę sportową i matka zbyt późno spostrzegła, że córka może mieć problemy z dostaniem się do szkoły średniej). 
Przedstawione propozycje są interesujące, ale wymagają dużej świadomości teoretycznej nauczyciela, nawet jeśli będzie on wspomagany przez dydaktyków uniwersyteckich. Natomiast krytyka tradycyjnego systemu kształcenia językowego, pojawienie się nowych propozycji, odrzucenie lub ograniczenie celów autonomicznych w nauce o języku oraz ograniczenie liczby godzin na realizację treści programowych spowodowało, że współczesne kształcenie językowe obrało niekorzystny kierunek. W szkole nie zadomowiła się żadna z nowych koncepcji, natomiast koncepcja tradycyjna została wypaczona. Teoria językowa przekazywana jest najczęściej w sposób dedukcyjny ${ }^{24}$, ćwiczenia językowe natomiast wykonywane są mechanicznie i ograniczają się do zadań i poleceń podręcznikowych ${ }^{25}$. Takie podejście do treści językowych w szkole skutkuje brakiem elementarnej wiedzy uczniów z zakresu szkolnej nauki o języku. Studenci polonistyki zgłębiający tajniki zawodu nauczyciela zamiast na strategiach pracy nad językiem ucznia i atrakcyjnych dla niego sposobach wprowadzania wiedzy z zakresu poszczególnych działów, koncentrują się na teorii językowej (np. notują definicje pojęć), którą powinni wynieść ze szkoły. Jeśli więc dalej podążymy tą drogą, wytworzymy sytuację, przed którą stanęli dydaktycy dwudziestolecia międzywojennego, walczący o autonomiczne cele nauki o języku, i zaczniemy odkrywać osiągnięcia dydaktyki polskiej, na przykład prace Zenona Klemensiewicza, Michała Jaworskiego, Jana Tokarskiego i wielu innych ${ }^{26}$. W tej sytuacji trudno nie opowiedzieć się za dotychczasowym modelem kształcenia językowego i sięgnąć do wypróbowanych sposobów. Warto też pamiętać o powstałych przed ćwierćwieczem pracach Reginy Pawłowskiej, ujmujących kompleksowo kształcenie umiejętności czytania i uwzględniających aspekt komunikacyjny w kształceniu językowym w zakresie umiejętności nadawczo-odbiorczych tekstu ${ }^{27}$. Publikacje uczonej przywoływane są okazjonalnie i fragmentarycznie, co świadczy o niedocenianiu jej myśli. A szkoda, jej propozycja jest jak najbardziej aktualna i do tego sprawdzona, ponadto w wielu działaniach ucznia i nauczyciela zbieżna z propozycją J. Kowalikowej.

24 Do takich wniosków skłania obserwacja przygotowywania przez studentów samodzielnych lekcji. Dyktowanie wiadomości z zakresu teorii językowej wydaje się powszechne. Wcześniej też występowało, ale nie było nagminne. Na uwagę, że dyktowanie wiadomości jest najgorszym sposobem przekazywania wiedzy, oburzony praktykant pyta z wyrzutem: to jak to zrobić inaczej?

25 Por. E. Horwath, Obraz lekcji z zakresu ksztatcenia językowego w gimnazjum, „Polonistyka. Innowacje" 2015, nr 2, http://pressto.amu.edu.pl/index.php/pi/article/view/4190/4256 [dostęp: 11.09.2016].

${ }^{26}$ Przypomnijmy niektóre prace wyznaczające kierunki pracy szkolnej nauczyciela w zakresie nauki o języku: S. Szober, Zasady nauczania języka polskiego w zakresie szkoły powszechnej i gimnazjum niższego, Lwów-Warszawa 1923; Z. Klemensiewicz, Cel nauczania gramatyki języka ojczystego w szkole, [w:] Ze studiów nad językiem i stylem, Warszawa 1969, s. 251-262; idem, Wybrane zagadnienia metodyczne z zakresu nauczania gramatyki, Warszawa 1959; M. Jaworski, Metodyka nauki o języku ojczystym, Warszawa 1978; J. Tokarski, Gramatyka w szkole. Podstawowe zagadnienia metodyki, Warszawa 1966, i inne.

27 R. Pawłowska, Lingwistyczna teoria nauki czytania, Gdańsk 1992, wydana później pod rozszerzonym tytułem: Czytam i rozumiem..., Kielce 2009; eadem, Metodyka ćwiczeń w czytaniu, Gdańsk 2003. 
Nietrudno zauważyć, że pisząca te słowa opowiada się za sięgnięciem do sprawdzonych sposobów kształcenia językowego. Za ważną uznaje także realizację autonomicznych celów nauki o języku, w takim jednak zakresie, by nauczanie teorii językowej miało charakter funkcjonalny. Uczeń w trakcie pracy nie tylko powinien mieć świadomość potrzeby zapoznawania się z tą teorią, ponieważ będzie z niej korzystał lub odwoływał się do niej w bliższej i dalszej przyszłości, lecz także powinien wiedzieć i odczuwać, że uczy się o zjawisku towarzyszącym ludzkości od zarania dziejów, a jemu od chwili narodzin. Szkolna nauka o języku powinna też uświadamiać uczniowi, że w języku zapisana jest historia jego narodu, a od umiejętności sprawnego posługiwania się językiem zależy jego powodzenie w życiu. Nauczanie funkcjonalne wymaga rozpatrywania faktów językowych w kontekście i odwoływania się do przykładów wziętych z żywego języka, także z języka ucznia, na co wskazywała między innymi M. Nagajowa ${ }^{28}$.

Warto zauważyć, że lekcjom językowym wcale nie musi zagrażać nuda, czego obrońcy teorii językowej w szkole się obawiali ${ }^{29}$. Niosą one przecież wiedzę o człowieku i jego kulturze i nawet — zadałoby się - wyjątkowo nudne i trudne tematy można uczynić interesującymi i kształcącymi ${ }^{30}$. Bardzo interesujące dla

${ }^{28}$ M. Nagajowa, Nauka o języku dla nauki języka. Na ten temat też eadem, Jak uczyć języka polskiego w klasach 4-6? Poradnik metodyczny, Warszawa 1995.

29 J. Puzynina, op. cit., s. 238.

30 Mając przed trzydziestoma laty przekazać uczniom klasy piątej wiedzę o obocznościach w tematach fleksyjnych, zastanawiałam się, co może zobaczyć jedenastolatek: w jednym wyrazie coś mu zniknie, w innym jedna ,literka” zamieni się z inną. I co z tego ma dla niego wynikać? Nuda tylko i obowiązek. Pomysł na rozwiązanie tego problemu nasunął się tuż przed wejściem do klasy. Zaczęłam od rozmowy o dziecku: kto ma braciszka lub siostrzyczkę?, czy ktoś zauważył, że dziecko zaraz po urodzeniu miało niebieskie oczy, a później stały się one brązowe?, a może dziecko urodziło się łyse albo miało czarne włosy, a później stały się one jasne i kręcone. Problem, co oczywiste, wyzwolił zainteresowanie, które zaowocowało przytaczaniem przykładów rozmaitych zmian. Padło wówczas „fundamentalne” pytanie: „A może to inne dziecko, bo ktoś je podmienił?”. Rozbawieni tym przypuszczeniem uczniowie szybko udowodnili, że takie przypuszczenie to oczywisty absurd i w ten sposób przeszłam do języka: „Z językiem jest tak jak z człowiekiem: rodzi się, zmienia i umiera, jeśli wymierają ci, którzy się nim posługują [uczniowie podali łacinę jako przykład języka martwego]. Te zmiany, chociaż zaszły bardzo dawno, możemy zobaczyć jeszcze dzisiaj”. Odwołałam się wówczas do jerów, które dzieci znały z nauki języka rosyjskiego, i na jednym przykładzie (miód - miodb) pokazałam, jak i dlaczego nastąpiła zmiana, zaznaczając, że to tylko przykład i nie trzeba tego zapamiętywać. Poinformowałam, że głoska zwana jerem była to trwająca bardzo krótko samogłoska, a że nasi przodkowie byli tak samo ,pracowici” jak my, zaczęli podczas mówienia tak ją skracać, aż zaniknęła. Stosując zasadę uproszczonego, ale nie fałszywego opisu języka doszliśmy od wyrazu miód w formie podstawowej do miod/u w przypadkach zależnych. Pojawiła się nawet informacja, jak i dlaczego dawni drukarze utrwalili nam w piśmie „ó", a istnienie języka polskiego i rosyjskiego podano jako przykład zmian zachodzących w języku starszym od obu języków: w języku prasłowiańskim. Nadmieniłam, że dziś jeszcze możemy odnaleźć dowody zmian zachodzących w tym języku, na przykład w wyrazach „duch” i „dusza”, „,noga” i „nodze”, „ręka” i „ręce”. Później zadaniem uczniów było poszukanie w podanych wyrazach innych śladów zmian w języku, wyszukanie odpowiednich przykładów (podanie par wyrazowych) i samodzielne sformułowanie wniosku z lekcji. Wywoławszy uwagę mimowolną uczniów i dając im konkret, 
ucznia mogą być, na przykład, lekcje z fonetyki, poświęcone powstawaniu głosu i artykulacji głosek, dotyczą go przecież w sposób bezpośredni. Może on nawet stać się dla siebie pomocą naukową i przez czucia mięśniowo-ruchowe i proste czynności obserwować, jak powstaje głos i poszczególne głoski ${ }^{31}$. To podstawowy sposób zainteresowania językiem, które zaowocuje wiedzą wykorzystywaną na innych lekcjach językowych, a także na lekcjach literackich.

W nauczaniu fleksji już na samym początku pracy można wyjść od obserwacji odpowiednio spreparowanego tekstu, w którym wszystkie wyrazy będą zapisane w formie podstawowej, na przykład: „Przeżyć niemiła przygoda. Podczas wakacyjny wycieczka kolega zaatakować pies. Zacząć na on głośno szczekać i warczeć. Zdenerwowany zwierzę zaatakować ja. Podnieść wysoko noga. Ten ruch dodatkowo rozzłościć rozjuszony czworonóg. Hałas zwabić inny zwierzę. Zbiec się chyba wszystko, co żyć na wieś". Jego analiza lub próba ujednoznacznienia za pomocą form fleksyjnych (na razie jeszcze bez nazywania czegokolwiek) pozwoli uczniom zauważyć, że tekst jest niezrozumiały lub że można go różnie rozumieć $^{32}$. Dalszy rozwój lekcji uzależniony jest od kierunku pracy i zainteresowania uczniów. Można zapytać, co powoduje, że tekst jest niezrozumiały, czego w nim brakuje, co zrobić, by nie budził żadnych wątpliwości. Powoli uczniowie dojdą do wniosku, że do rozumienia ważne są cząstki (końcówki; dalsza odpowiednio ukierunkowana obserwacja pozwoli zauważyć część stałą wyrazu, za którą kryje się znaczenie, i zmienność końcówek), które w jakiś sposób decydują o znaczeniu (mają określone funkcje składniowe). Na tym tle łatwiej będzie dziecku zrozumieć odmianę przez przypadki i osoby ${ }^{33}$, a nauczycielowi wprowadzać w tajniki języka polskiego jako języka fleksyjnego. Proponowane rozwiązanie uświadamia, dlaczego nauczanie fleksji należy łączyć ze składnią. Takie postępowanie jest zasadą dydaktyczną, nie zawsze jednak jest ona respektowana.

Ważne jest uzmysłowienie uczniom, że mechanizmy (teorię), które poznają na lekcjach słowotwórstwa, stosują na co dzień, choć czynią to nieświadomie (nabyli je w dzieciństwie wraz z nauką języka). Na lekcji wprowadzającej do tego

do którego mogli się odnieść (mimo że z językiem nie miał on związku, zastosowałam zasadę stopniowania trudności i przeszłam od tego, co bliskie, do tego, co dalekie), mogłam odwołać się do abstraktu. Zastosowane przeze mnie opowiadanie pedagogiczne trwało bardzo krótko - tyle tylko by pokazać, jak zanik jeru wydłużył artykulację sąsiedniej głoski, a kolejne procesy językowe dały nam [u] zapisywane jako „ó”). Tak niewiele trzeba, by uczeń wyszedł z lekcji zadowolony, a trudną wiedzę zapamiętał.

31 Zob. np. J. Fiszbak, Nauczanie fonetyki w szkole, [w:] Z dydaktyki języka ojczystego w szkole, red. S. Gala, Łódź 1996, s. 59-72.

32 Tekst wyjściowy brzmiał: „Przeżyłem niemiłą przygodę. Podczas wakacyjnej wycieczki kolega zaatakował psa. Zaczął na niego głośno szczekać i warczeć. Zdenerwowane zwierzę zaatakowało mnie. Podniosłem wysoko nogi. Ten ruch dodatkowo rozzłościł rozjuszonego czworonoga. Hałas zwabił inne zwierzęta. Zbiegło się chyba wszystko, co żyło w na wsi”.

33 O tym, że wprowadzana tradycyjnie odmiana wyrazów jest dla dziecka abstrakcją i może wywoływać zamęt, choć wydaje się tak prosta i oczywista, świadczy odpowiedź jedenastolatki na pytanie: przez co odmienia się czasownik — czasownik odmienia się przez liczby i człowieka. 
działu możemy zaproponować pracę $\mathrm{w}$ grupach i rozpatrzenie następującego zestawu wyrazów (wszystkie grupy otrzymują ten sam zestaw wyrazów i zadań do rozwiązania): lukać, luknąć, oblukać; ksero, kserować, przekserować, skserować, kserowy (papier); lajk, lajkować, zlajkować, zlajkowany, zalajkować; hejt, hejtować, zhejtować, zhejtowany; e-mail, mejl, mejlować, mejlowy, przemejlować; SMS, esemes, esemesowy, esemesować, esemesowany, czat (chat), czatować, czatowy, poczatować; ban, banować, zbanować, zbanowany; design, designerski, designer, designerka; blog, bloger, blogerka. Zadaniem grup byłaby odpowiedź na pytania/rozwiązanie zadań: $Z$ jakiego języka pochodzą przytoczone wyrazy (podajcie wyraz wyjściowy każdej grupy)? Wytłumaczcie znaczenie tych słów. Dlaczego te wyrazy znalazły się w naszym języku? W jaki sposób te wyrazy zostały przystosowane do języka polskiego? Czy wszystkie wskazane grupy wyrazów mogą występować w języku polskim na tych samych zasadach (czy ich występowanie jest uzasadnione?, jaką funkcję pełnią w języku użytkowników?)? Wskaż grupę, która powstała najwcześniej; co o tym może świadczyć? W jaki sposób bogacimy słownictwo naszego języka? Ostatnie pytanie jest punktem wyjścia do rozważań lekcyjnych: uczniowie powinni wskazać zapożyczenia oraz tworzenie nowych wyrazów od innych na wzór już istniejących w języku. Jeśli mieliby z tym problemy, możemy im podpowiedzieć, wskazując odpowiednie grupy wyrazów (Przyjrzyjcie się podanym parom wyrazów i sformułujcie wniosek informujący o tym, jak tworzymy nowe wyrazy), na przykład: designer — designerka; bloger — blogerka; nauczyciel — nauczycielka; lukać — luknąć, piszczeć — pisnąć; lajk — lajkować; ksero — kserować, kserować — kserowany; piasek — piaskować, piaskować — piaskowany. Jako pracę domową możemy zadać wypowiedzenie się na temat: Czy hejtowanie można uznać za przejaw agresji językowej lub za cyberprzemoc? lub: Jaka wiedzę o pochodzeniu wyrazów odkryto dziecko, które podszedtszy do mamy z grzebieniem, poprosito: „Mamo, pogrzeb mi włosy”?

Przejdźmy do innego działu nauki o języku. O tym jak ważne jest nauczanie składni i kiedy wiedzę z tego zakresu nauki o języku wykorzystujemy, pisała między innymi Elżbieta Awramiuk, broniąc obecności teorii językowej w szko$1 \mathrm{e}^{34}$. W tym miejscu warto wskazać na zanikanie w pracy nad składnią rozbiorów logicznych i gramatycznych zdania oraz wykresów zdań wielokrotnie złożonych. Niemal wszyscy studenci mają z tym problemy, a wielu twierdzi, że takich ćwiczeń nie wykonywało. Bardziej prawdopodobne jest, że ich nie pamięta, co też jest symptomatyczne. W przeszłości bywały one tak częste, że aż nużące. Współczesny nauczyciel, szukając czasu na realizację programu, ograniczył je do minimum, nie widząc sensu $\mathrm{w}$ ich wielokrotnym powtarzaniu. Tymczasem te ćwiczenia pomagają w rozkodowywaniu treści zdania i ustalaniu związków

34 E. Awramiuk, O walorach kształcacych składni, [w:] Z problematyki ksztatcenia językowego, t. 2. Składnia - teoria a praktyka szkolna i akademicka, red. H. Sędziak, Białystok 2002, s. 229-239, za: http://repozytorium.uwb.edu.pl/jspui/bitstream/11320/1156/1/Awramiuk_O_walorach_ksztalcacych_skladni_2002.pdf [dostęp: 28.12.2015]. 
między wyrazami, o ile jego analiza nie ograniczy się do wypreparowanych na użytek lekcji przykładów. R. Pawłowska zwraca uwagę na rolę analizy składniowej w świadomym odbiorze tekstu ${ }^{35}$. Jej spostrzeżenia potwierdza E. Awramiuk:

Rozumienie zdania polega na dostrzeganiu zależności składniowych między jego członami. Zwykle ich dostrzeżenie dokonuje się poza świadomością odbiorcy, istnieją jednak sytuacje, kiedy odczytanie sieci związków syntaktycznych bywa problematyczne. Właśnie wtedy uruchamiana jest wiedza składniowa ${ }^{36}$.

Na odniesieniu się do tych działów szkolnej nauki o języku i zasygnalizowaniu problemu poprzestaniemy nie tylko ze względu na brak miejsca. Nie chodzi o to, by wskrzeszać przeszłość, która — jak wiadomo — nie zawsze dawała przykłady dobrej pracy nad językiem ucznia i budzeniem jego świadomości językowej. Istnieje przecież zasadnicza różnica między założeniami i ich realizacją. Złe przekazywanie wiedzy o języku nie jest też normą dzisiaj. Idzie tylko o uzmysłowienie, że teoria językowa nie jest zbędnym balastem lub niepotrzebnym obciążaniem pamięci nieprzydatnymi informacjami. Podana w sposób interesujący i zdobyta w sposób kształcący może wywołać refleksję nad językiem, która przyczyni się/może się przyczynić do kształtowania kultury językowej. Jej istnienie lub też jej brak zaczyna budzić coraz większy niepokój ${ }^{37}$.

Jak wcześniej wspomniano, rozwijaniu umiejętności językowych miały służyć ćwiczenia w mówieniu i pisaniu. I w tym miejscu możemy wrócić do przywołanej na początku pozycji K. Pojawskiej i powołać się na inne, o podobnym charakterze $^{38}$. Dydaktycy szkolni i akademiccy wypracowali na przestrzeni lat teorię kształcenia, która zwracała uwagę na zasady pracy nad językiem ucznia. Możemy tu wymienić, na przykład, zasadę łączności ćwiczeń w pisaniu z ćwiczeniami w mówieniu, równomiernego kształcenia języka mówionego i pisanego, poprzedzania ćwiczeń w pisaniu ćwiczeniami w mówieniu. Dokładnie opracowano formy ćwiczeń: ćwiczenia słownikowo-frazeologiczne, gramatyczno-stylistyczne, składniowe, ortograficzne, interpunkcyjne, kompozycyjne, redakcyjne, w czytaniu, w recytacji i estetycznym wygłaszaniu, w korzystaniu ze słowników. Zwrócono również uwagę na sposoby wprowadzania form wypowiedzi. Dysponujemy także szczegółowymi opracowaniami form wypowiedzi w zakresie ich budowy i znaczenia pracy nad nimi dla rozwijania języka ucznia. Taka wiedza powinna zaowocować wymiernymi efektami, a jednak są one niezadowalające. Przyczyny

35 R. Pawłowska, Lingwistyczna teoria nauki..., s. 50-61.

36 E. Awramiuk, op. cit., s. 230.

37 Zob. np. M. Madejowa, Kultura językowa Polaków (zarys problematyki), [w:] Szkolna polonistyka zanurzona..., s. 44-62.

38 Np. zob. M. Kniagininowa, Prace z języka polskiego w klasach V-XI, Warszawa 1966; M. Nagajowa, Ćwiczenia w mówieniu i pisaniu, Warszawa 1977; eadem, Kształcenie języka ucznia w szkole podstawowej, Warszawa 1985; E. Polański, K. Orłowa, Kształcenie językowe w klasach 4-8. Poradnik metodyczny, Warszawa 1993; Z.A. Kłakówna, Sztuka pisania. Ćwiczenia redakcyjne dla klas IV-VI. Zeszyt ucznia; oraz eadem, Sztuka pisania. Ćwiczenia redakcyjne. Metodyczny poradnik nauczyciela, Kraków 1993, i inne. 
tego stanu rzeczy wynikają z zarzucenia lub ograniczenia realizacji tych ćwiczeń w szkole, co pociąga za sobą ograniczenie ich wielostronnego oddziaływania na język dzieci. Dalej — dla przykładu — zwrócimy uwagę na kształcące oddziaływanie wybranych ćwiczeń.

Zacznijmy od ćwiczeń kompozycyjnych. Kto dziś w szkole poleca uczniom układanie planów? W podręcznikach znajdujemy zadania, których celem jest ułożenie punktów planu zgodnie $\mathrm{z}$ wydarzeniami $\mathrm{w}$ utworze. Takie polecenia służą w zasadzie tylko przypomnieniu treści. Tymczasem ćwiczeniom kompozycyjnym stawia się też inne cele: odkrycie kompozycji utworu, uporządkowanie wydarzeń zgodnie z następstwem czasu, wybór najważniejszych wydarzeń (rozwijanie rozumienia tekstu), ułatwienie przedstawienia treści utworu (rozwijanie umiejętności mówienia) lub napisania opowiadania (rozwijanie umiejętności pisania), poszukiwanie równoważnego ekwiwalentu tekstu (ćwiczenia w parafrazie, ćwiczenie uczenia się), układanie planu w wybranej formie językowej (ćwiczenia składniowe, stylistyczne, rozwijanie/kształtowanie umiejętności językowych); wprawianie się do formułowania notatki w formie planu, ćwiczenie umiejętności zapisu myśli w punktach. Wystarczy tych tylko przykładów, by stwierdzić, jak wiele uczeń traci, jeśli nie wykonuje ćwiczeń kompozycyjnych.

Podobnie jest w przypadku zarzucenia ćwiczeń ortograficznych. Dziś uczniowie wypełniają głównie teksty z lukami, które w bardzo ograniczonym stopniu wpływają na nabywanie sprawności ortograficznej. Jerzy Bralczyk w jednym $\mathrm{z}$ wywiadów telewizyjnych stwierdził, że w sprawach ortografii zawsze radził swoim studentom, by machinalnie napisali wyraz, jeśli mają problemy natury poprawnościowej. Wyraz zapisany jako pierwszy z dużym prawdopodobieństwem można uznać za napisany poprawnie. Dodać jednak należy, że będzie tak tylko wówczas, gdy obecni studenci ćwiczyli jako uczniowie pisownię wyrazów w szkole (wyćwiczyli pamięć motoryczną - idzie tu o pamięć ruchu ręki powiązaną z pisaniem wyrazu). W nabywaniu sprawności ortograficznej nie pomoże także komputer ani też nie rozwiąże problemów za piszącego (chyba że ten zechce szybko sprawdzić pisownię wyrazu w internetowym słowniku, już jednak w przypadku homonimów problemy trzeba będzie rozstrzygać inaczej). Sprawność ortograficzna nie stanowi dziś wyznacznika kultury językowej. Jeśli tekst jest zrozumiały, ortografia nie powinna wpływać znacząco na jego ocenę — taka „zasada” zaczęła obowiązywać na przełomie XX i XXI w. Zapomniano jednak, że ortografia nie ogranicza się tylko do pisowni $u$ i $o, \dot{z}$ i $r z, c h$ i $h$ i nie tylko z tymi trudnościami uczniowie mają problemy, a ograniczenie wymagań ortograficznych zaczęło wespół z innymi czynnikami sprzyjać bylejakości. Warto zauważyć, że różnorodne ćwiczenia ortograficzne sprzyjają utrwalaniu znaczenia wyrazu oraz jego struktury, co z kolei powoduje, że wyraz jest szybciej rozkodowywany podczas czytania (wyrazy odczytujemy całościowo, uwzględniając jego długość, pierwszą i ostatnią sylabę, elementy wystające do góry i do dołu; znaczenie wyrazu odnosimy do własnych doświadczeń życiowych, natomiast rozkodowywanie znaczenia zdania i tekstu jest za każdym 
razem czynnością twórczą $\left.{ }^{39}\right)$. W dydaktyce przedmiotu wielokrotnie podkreślano, że osoby dużo czytające piszą poprawnie pod względem ortograficznym ${ }^{40}$. Ukuto nawet stwierdzenie, że częste czytanie wpływa na sprawność ortograficzną. Wydaje się jednak, że zależność może być też odwrotna. Znajomość struktury wyrazów wpływa na szybkość ich odczytania/rozumienia, co z kolei powoduje mniejszą liczbę zatrzymań w trakcie czytania i nie utrudnia rozkodowywania tekstu.

Zauważono wcześniej, że fleksji należy uczyć łącznie ze składnią. Podobnie należy postępować podczas ćwiczeń interpunkcyjnych. Tymczasem interpunkcji od dawna uczyło się w sposób podający, ograniczając się do podyktowania lub odczytania reguł z podręcznika i polecenia ich opanowania. Ostatnio zrezygnowano nawet ze sprawdzania ich znajomości, i słusznie — znajomość reguł tylko w niewielkim stopniu wpływa na sprawność interpunkcyjną, a same reguły stosowane mogą być tylko okazjonalnie w młodszych klasach. Ten typ ćwiczeń zarzucono najwcześniej, toteż problemy interpunkcyjne Polaków znane są od bardzo dawna. Z tego właśnie powodu należy kształtowaniu tej sprawności poświęcić więcej uwagi. Doskonałym ćwiczeniem interpunkcyjnym jest zadanie rozczłonowania dłuższego tekstu (przynajmniej półstronicowego) pisanego ciągiem, małymi literami (także w przypadku nazw własnych) i uzupełnienie go odpowiednimi znakami interpunkcyjnymi. Zadanie to wymaga wczytania się w tekst i dokładnego jego zrozumienia, by można było go podzielić na jednostki składniowe i wstawić odpowiednie znaki, także te wynikające z reguł. Tego typu ćwiczenia uczą nie tylko rozumienia istoty rozczłonowywania tekstu pisanego oraz funkcji znaków interpunkcyjnych. Pozwalają na świadome stosowanie znaków podczas pisania tekstów własnych, zwracają również uwagę na ortografię. Wreszcie, ćwiczą sprawność czytania/rozumienia tekstów. Ich funkcja jest więc wieloraka. To ćwiczenie jest bardzo trudne, toteż może być stosowane tylko do uczniów po dwunastym roku życia (w tym mniej więcej czasie zaczyna się rozwój myślenia abstrakcyjnego). Wcześniej, u uczniów młodszych, doskonale sprawdzą się teksty jedno-, dwuzdaniowe (liczbę zdań stopniowo można zwiększać) oraz powiązanie analizy składniowej z interpunkcyjną podczas rozbiorów i wykresów zdań.

Zamknijmy problem ćwiczeń w mówieniu i pisaniu zmianami, jakie zaszły w zakresie liczby prac pisemnych, które powinien uczeń napisać w trakcie semestru. Ile dłuższych prac stylistycznych piszą dzisiaj uczniowie? Kiedyś — trzy klasowe i kilka domowych w semestrze, dzisiaj nierzadko — jedna klasowa i jedna, dwie domowe. Ilościowo podobnie rzecz się przedstawia w przypadku

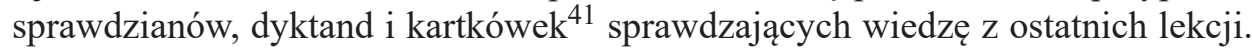

39 R. Pawłowska, Lingwistyczna teoria nauki...

40 Zob. np. E. Polański, Dydaktyka ortografii i interpunkcji, Warszawa 1995.

41 Jak dowiedziałam się od koleżanek nauczycielek po szkoleniu, wyraz „,kartkówka” jest od jakiegoś czasu na cenzurowanym — wręcz dyskredytuje nauczyciela, jeśli go używa. Ciekawe, jak długo jeszcze będziemy spotykać się z podobnymi, nic niewnoszącymi poprawkami. Martwimy się o kulturę językową Polaków, chcemy, by uczniowie ją respektowali, a na własnym podwórku toleru- 
W przypadku tych ostatnich wielu nauczycieli koncentruje się na wiadomościach, które uczeń posiadł, i w mniejszym stopniu na formie, w jakiej je przekazuje. Bywa, że w ogóle nie jest ona uwzględniana, nic więc dziwnego, że studenci swoje prace oddają w stanie urągającym wszelkim normom i nie są to przypadki odosobnione. Warto też przypomnieć okres pisania „na ilość”, na przykład: „Napisz w dziesięciu / siedmiu / pięciu zdaniach...”. Nie wpłynął on korzystnie na umiejętności stylistyczne uczniów. Podstawą kształtowania sprawności językowej ucznia jest praca nad jego językiem pisanym i ciągła kontrola osiągnięć w tym zakresie. Między liczbą prac pisemnych a sprawnością językową, która rzutuje również na osiągnięcia ucznia w nauce, zachodzi dość charakterystyczna prawidłowość: sukcesy szkolne (nie tylko w zakresie języka polskiego) odnoszą ci uczniowie, których poloniści bezustannie obłożeni są zeszytami domowymi, klasowymi, dyktandami, sprawdzianami i kartkówkami (oczywiście jest to pewne uproszczenie, ponieważ na umiejętności językowe ucznia wpływ mają również inne działania jego polonisty).

Pora na podsumowanie. Zmiany ogólnokulturowe niewątpliwie wpływają na poziom i umiejętności językowe Polaków. Oddziaływanie mediów na język i komunikowanie się za ich pomocą rodzi specyficzne zmiany. Także ogólnie łatwo dostępne kształcenie uniwersyteckie powoduje napływ do szkół wyższych młodzieży nieprzygotowanej odpowiednio do studiów, a nie jest to czas na kształtowanie podstawowych umiejętności językowych i formowanie poziomu intelektualnego. Człowiek uczy się i rozwija przez całe życie, jednak określony zasób umiejętności powinna mu dać szkoła ogólnokształcąca. Nie w przemianach ogólnokulturowych należy więc poszukiwać głównych przyczyn niekorzystnych zmian w posługiwaniu się językiem przez ogół Polaków. Odpowiedzialnością za ten stan obarczyć należy system kształcenia ogólnego, uzawodowienie szkoły, odrzucenie wiedzy jako wartości nadrzędnej, reorganizację systemu kształcenia, w tym cięcia w siatkach godzin przeznaczonych na realizację materiału. Przyczyną niepożądanych zmian jest również rozchwianie systemu kształcenia językowego.

Opowiedzenie się za sięgnięciem do sposobów wypracowanych przez dydaktyków i nauczycieli, w których było miejsce na realizację autonomicznych celów nauki o języku oraz ćwiczenia w mówieniu i pisaniu, nie jest podyktowane uznawaniem ich za model tak doskonały, by odrzucić poszukiwania innych strategii kształcenia. Wprowadzając do szkoły nowe koncepcje, należy postępować

jemy jej naruszanie. Sądziłam, że czas szkieletów rybich, rybek w akwarium, pokerów kryterialnych itp. już minął, ale — niestety — okres radosnej twórczości trwa nadal: pojawiło się „nacobezu”. Najpierw infantylizacja procesu dydaktycznego, teraz - tolerowanie tendencji do skrótów. Nikt nie protestuje też przeciw nadawaniu nowych, błędnych znaczeń starym wyrazom, np. kreatywny — w znaczeniu: pomysłowy, zarządzanie informacją — w znaczeniu: korzystanie $\mathrm{z}$ informacji; istnieją też dwa wyrazy odnoszące się do sposobu pracy ucznia i nauczyciela na lekcji: metoda i metoda aktywizująca (a która metoda nie jest aktywizująca?). To tylko przykłady. Jeśli nauczyciel zmuszony jest rozkodowywać tego typu „nowinki dydaktyczne”, to nic dziwnego, że zaczyna mu brakować czasu na pracę z uczniem. 
ostrożnie. Wydaje się, że w tym przypadku celowe jest pozostawienie wyboru nauczycielowi, zgodnie z zasadą jego podmiotowości. Powinnością polonisty jest ukształtowanie języka ucznia i uformowanie go intelektualnie. Jak to uczyni powinno zależeć od niego, sposobów, które wydają mu się najlepsze, i koncepcji mu najbliższej.

\section{Bibliografia}

Bakuła K., Szkolna naukę o języku trzeba zmienić, „Polonistyka” 1994, nr 5, s. 274-281.

Fiszbak J., Nauczanie fonetyki w szkole, [w:] Z dydaktyki języka ojczystego w szkole, red. S. Gala, Łódź 1996, s. 59-72.

Fiszbak J., O celach szkolnej nauki o języku, [w:] Z dydaktyki języka ojczystego w szkole, red. S. Gala, Łódź 1996, s. 7-26.

Gajda S., Trudne upotrzebnienie, „Polonistyka” 1996, nr 6, s. 240-241.

Horwath E., Teorie językoznawcze w szkolnej dydaktyce, [w:] Szkolna polonistyka zanurzona w ję$z y k u$, red. A. Janus-Sitarz, E. Nowak, Kraków 2014, s. 63-86.

Jaworski M., Metodyka nauki o języku ojczystym, Warszawa 1978.

Klemensiewicz Z., Cel nauczania gramatyki języka ojczystego w szkole, [w:] idem, Ze studiów nad językiem i stylem, Warszawa 1969, s. 251-262.

Klemensiewicz Z., Wybrane zagadnienia metodyczne z zakresu nauczania gramatyki, Warszawa 1959.

Kłakówna Z.A., Sztuka pisania. Ćwiczenia redakcyjne. Metodyczny poradnik nauczyciela, Kraków 1993.

Kłakówna Z.A., Sztuka pisania. Ćwiczenia redakcyjne dla klas IV-VI. Zeszyt ucznia, Kraków 1993.

Kniagininowa M., Prace z języka polskiego w klasach V-XI, Warszawa 1966.

Kowalikowa J., Od stowa do zdania, od zdania do tekstu — od tekstu do zdania, od zdania do stowa, [w:] Szkolna polonistyka zanurzona w języku, red. A. Janus-Sitarz, E. Nowak, Kraków 2014, s. $17-43$.

Madejowa M., Kultura językowa Polaków (zarys problematyki), [w:] Szkolna polonistyka zanurzona w języku, red. A. Janus-Sitarz, E. Nowak, Kraków 2014, s. 44-62.

Nagajowa M., Ćwiczenia w mówieniu i pisaniu, Warszawa 1977.

Nagajowa M., Jak uczyć języka polskiego w klasach 4-6? Poradnik metodyczny, Warszawa 1995.

Nagajowa M., Kształcenie języka ucznia w szkole podstawowej, Warszawa 1985.

Nagajowa M., Nauka o języku dla nauki języka. Poradnik metodyczny dla nauczycieli języka polskiego, Kielce 1994.

Nieckula F., Primum non nocere, „Polonistyka” 1996, nr 6, s. 241-242.

Nieckula F., Usunąć język polski z „,języka polskiego”?, „Polonistyka 1995, nr 4, s. 214-220.

Nocoń J., Uczenie o języku polskim po 1998 roku — prognozy i koncepcje dydaktyczne, [w:] Uczeń w świecie języka i tekstów, red. J. Nocoń, E. Łucka-Zając, Opole 2010, s. 27-37.

Pawłowska R., Czytam i rozumiem Lingwistyczna teoria nauki czytania, Kielce 2009.

Pawłowska R., Lingwistyczna teoria nauki czytania, Gdańsk 1992.

Pawłowska R., Metodyka ćwiczeń w czytaniu, Gdańsk 2003.

Pojawska K., Ćwiczenia w mówieniu i pisaniu w klasach V-VIII, Warszawa 1967.

Polański E., Dydaktyka ortografii i interpunkcji, Warszawa 1995.

Polański E., Orłowa K., Kształcenie językowe w klasach 4-8. Poradnik metodyczny, Warszawa 1993.

Puzynina J., Gramatyka na 10 głosów, „Polonistyka” 1996, nr 6, s. 238-239. 
Rypel A., Nauczanie komunikacyjne w kształceniu uczniowskich wypowiedzi pisemnych. Problemy. Badania eksperymentalne. Implikacje dydaktyczne, Bydgoszcz 2007.

Szober S., Zasady nauczania języka polskiego w zakresie szkoły powszechnej i gimnazjum niższego, Lwów-Warszawa 1923.

Tokarski J., Gramatyka w szkole. Podstawowe zagadnienia metodyki, Warszawa 1966.

Zbróg P., Wojna o ksztatcenie językowe, Kielce 2005.

Zgółka T., Barbarzyńca w (szkolnym) ogrodzie, „Polonistyka” 1995, nr 4, s. 213-214.

\section{Źródła internetowe}

Awramiuk, E., O walorach ksztatcacych sktadni, [w:] Z problematyki ksztatcenia językowego, t. 2. Składnia - teoria a praktyka szkolna i akademicka, red. H. Sędziak, Białystok 2002, s. 229-239, http:// repozytorium.uwb.edu.pl/jspui/bitstream/11320/1156/1/Awramiuk_O_walorach_ksztalcacych_ skladni_2002.pdf [dostęp: 28.12.2015].

Horwath E., Obraz lekcji z zakresu ksztatcenia językowego w gimnazjum, „Polonistyka. Innowacje” 2015, nr 2, http://pressto.amu.edu.pl/index.php/pi/article/view/4190/4256 [dostęp: 11.09.2016].

Pamięci Karoliny Pojawskiej, http://www.um.kielce.pl/pomitab/obiekty/pojawska [dostęp: 28.12.2015].

Stankiewicz J., Nauczyciele tajnego nauczania, uczestnicy ruchu oporu 1939-1945 (województwo kieleckie), http://www.stankiewicze.com/index.php?kat=38\&sub=854 [dostęp 28.12.2015]. 